\title{
Development and validation of oral chemotherapy self-management scale
}

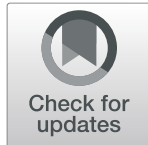

Qi Peng and Wanying Wu*

\begin{abstract}
Background: With the increase of oral chemotherapy drugs, patients receiving cancer treatment prefer oral chemotherapy versus intravenous, given equal efficacy and toxicity. However, they need to take an active part in their care, which is vital with home-based oral therapy, therefore the self-management is important for patients with oral chemotherapy. Unfortunately, the development of self-management assessment tools for oral chemotherapy still lags behind.

Methods: The OCSMS item pool was formulated based on literature review and semi-structured interviews, An initial scale containing 5 dimensions and 38 items was constructed through research seminar, Delphi survey and pilot testing. To assess the validity and reliability, We recruited 261 patients from cancer hospital in China.

Results: A 36-item scale was developed with five dimensions identified through factor analysis: daily life management, symptom management, medication management, emotional cognitive management and social support. Cronbach's coefficient Alpha, split-half coefficient, test-retest reliability and S-CVI/UA scores were 0.929, $0.773,0.966$ and 0.833 , respectively, indicating that OCSMS has good reliability and validity.

Conclusions: The OCSMS is a valid, reliable measurement method of the self-management ability of patients with oral chemotherapy. The OCSMS shows potential as a tool to ensure the safety of patients with cancer. The OCSMS may help evaluate the effectiveness of interventions to improve the self-management ability of patients.
\end{abstract}

Keywords: Cancer, Oral chemotherapy, Self-management, Validation

\section{Background}

Chemotherapy is one of the most important treatments for cancer, and the route of chemotherapy administration is developing continuously. With the spread of oral chemotherapy agents over the last 15 years, people are choosing oral chemotherapy because it is safe, economical and helps prevent venepuncture [1-3]. Patients are likely to choose oral chemotherapy than intravenous chemotherapy even with their same efficacy and toxicity [4].

With oral anticancer agents becoming widely common, a critical shift has occurred from clinic-based

\footnotetext{
*Correspondence: 764286275@qq.com

Cancer Hospital of the University of Chinese Academy of Sciences (Zhejiang Cancer Hospital), Institute of Cancer and Basic Medicine (IBMC), Chinese Academy of Sciences, East Banshan Road, Gongshu District, Hangzhou, Zhejiang, People's Republic of China 310022
}

healthcare provider-administered management to homebased self-administered management [5]. However, it also brings new challenges. For example, patients at home can't recognize the undesirable side effects, such as nausea and vomiting $[4,6]$. Hence, the patient's selfmanagement ability is very important.

Self-management was proposed by Corbin and Straus for chronic disease [7] and has been defined as managing symptoms, treatments, lifestyle alterations and psychosocial consequences of health conditions [8]. Selfmanagement has been widely used in all aspects of management. Numerous studies have shown that enabling effective self-management of medication in nonmalignant chronic diseases (i.e.,Hypertension) results in better disease control and a better quality of life $[9,10]$. Self-management is particularly important for patients

(c) The Author(s). 2020 Open Access This article is licensed under a Creative Commons Attribution 4.0 International License, which permits use, sharing, adaptation, distribution and reproduction in any medium or format, as long as you give appropriate credit to the original author(s) and the source, provide a link to the Creative Commons licence, and indicate if changes were made. The images or other third party material in this article are included in the article's Creative Commons licence, unless indicated otherwise in a credit line to the material. If material is not included in the article's Creative Commons licence and your intended use is not permitted by statutory regulation or exceeds the permitted use, you will need to obtain permission directly from the copyright holder. To view a copy of this licence, visit http://creativecommons.org/licenses/by/4.0/ The Creative Commons Public Domain Dedication waiver (http://creativecommons.org/publicdomain/zero/1.0/) applies to the data made available in this article, unless otherwise stated in a credit line to the data. 
with oral chemotherapy because it affects their adherence to the treatment, quality of life and safety $[11,12]$. To date, no effective evaluation tools have been designed to measure self-management for oral chemotherapy. The purpose of this study is to develop a valid and reliable instrument oral chemotherapy self-management scale (OCSMS).

\section{Methods}

This study is a prospective, mixed-method scale development of oral chemotherapy self-management scale (OCSMS). Figure 1 describes the development of this scale.

\section{Ethical approval}

This study was approved by the medical ethics committee of ZheJiang Cancer Hospital, Hangzhou, Zhejiang, China (IRB-2015-208).

\section{Item generation}

Literature review and semi-structured interviews were conducted to generate an item pool. A comprehensive literature review was performed to generate a semistructured interview guide, which was used for in-depth interviews [13]. Purpose sampling was adopted, involving 10 experts (including nurses, doctors and pharmacists) and 9 patients. Data were analysed using Nvivo11 software. A total of seventy-eight items and six domains of oral chemotherapy self-management were generated.

\section{Research seminar}

A total of seventy-eight items and six domains were scrutinized during two-round research seminar. Eight experts with a titles of deputy senior or above and bachelor's degree or above and six experts with master's degree or above and more than 3 years of relevant work experience were selected in the two-round research. Thirty items and four domains of oral chemotherapy self-management were chosen in the two-round research seminar.

\section{Delphi survey}

Two rounds of Delphi consultation were conducted. Eighteen experts (nurses, doctors and pharmacists) from eight provinces, including Shanghai, Beijing, Zhejiang and Hunan, were invited to evaluate the scale format and each item. All experts have a bachelor's degree and more than 10 years of relevant work experience. They read, evaluated and rated each item based on its clarity, uniqueness and relevance to oral chemotherapy selfmanagement. Items with a coefficient of variation $>0.25$ and average score $<3.5$ were removed $[14,15]$. We had removed one item, and had added nine items and one domain of oral chemotherapy self-management by using Delphi method.

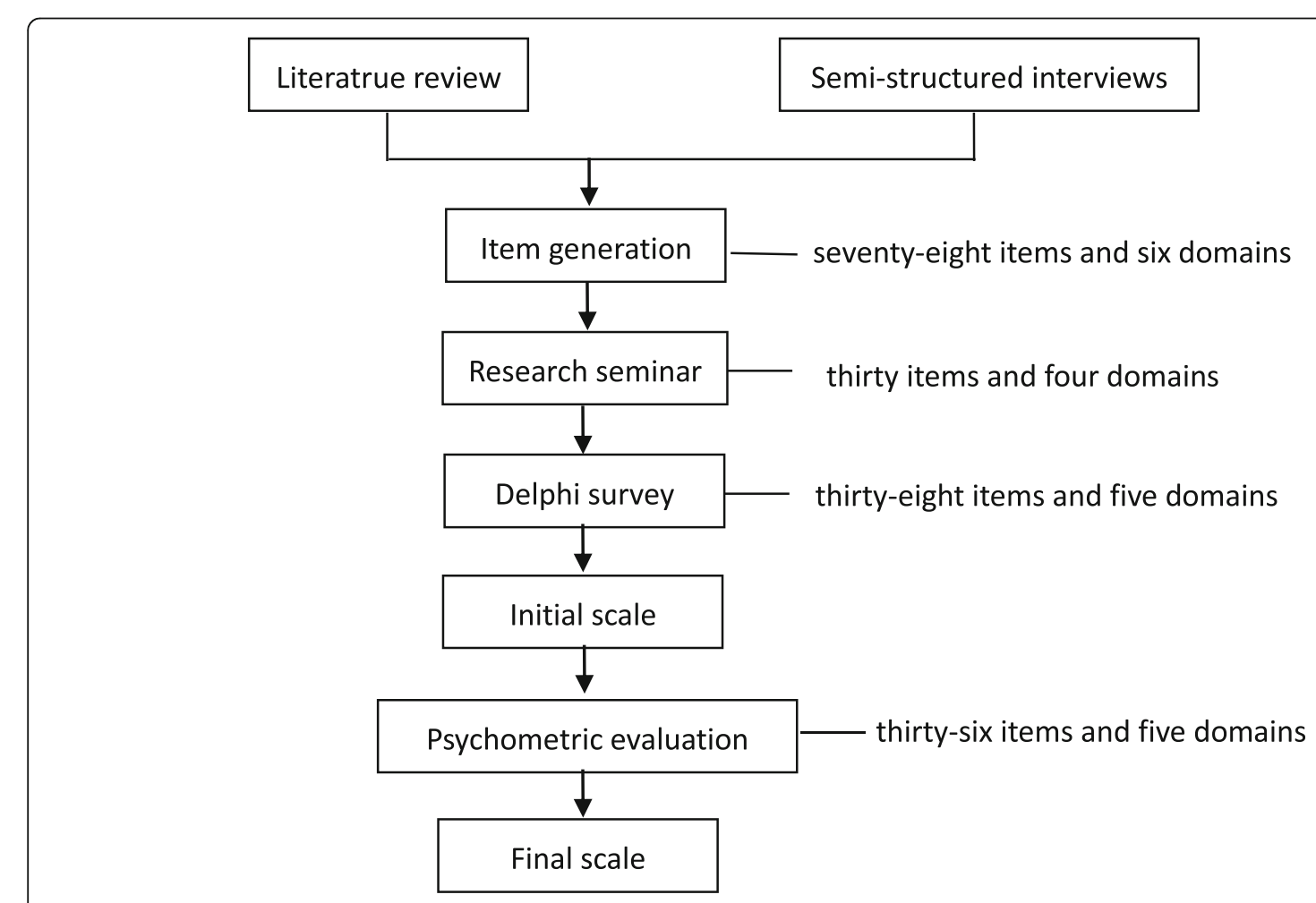

Fig. 1 Development of Oral Chemotherapy Self-management Scale 
Additional information on this study design, data analysis and results of literature review and Delphi survey can be found in previous publications $[15,16]$.

\section{Pilot testing}

Prior to undertaking the psychometric properties of the scale, we recruited 40 participants (20 females) for pilot testing. The mean age of 40 participants from Zhejiang Cancer hospital was $53.05 \pm 10.68$ years (range 27-73 years). The purpose of the pilot testing is to find possible administration problem, such as miss-phrasing, and to determine which items should be modified, added or removed. The researchers explained the purpose of the study, and gave an example before its completion for each participant. After the patients completed the scale, the researchers asked the patients whether they unable to respond. Through the pilot testing, we modified two items without adding or removing any items.

\section{Validity and reliability}

To evaluate the psychometric properties of the scale, we recruited 261 participants from Zhejiang Cancer hospital in China between May 12,018 and January 312,019. The minimum sample size for factor analysis should be five times the number of items with at least 200 cases [17]. For the test-retest reliability evaluation of the scale, 40 of the participants returned 2-5 weeks later to complete the same survey. Two participants withdrew from the study. The inclusion criteria were as follow: adults (more than 18 years old) with confirmed diagnosis of cancer, using an oral chemotherapy regimen, willing to participate, and able to communicate using Mandarin. The exclusion criterion was inability for self-care.

\section{Results}

\section{Characteristics of the participants}

The mean age of participants was 54.78 years $(\mathrm{min}=27$, $\max =83$ ). Among them, $59.4 \%$ were male, and $90.4 \%$ were married. Table 1 shows their selected demographic characteristics.

\section{Validity of the scale}

We removed two items through exploratory factor analysis. The value of KMO was 0.886 , and the result of Barlett's sphericity test was $\mathrm{X}^{2}=7106.941(\mathrm{df}=630, p=$ 0.000 ). These values indicated that the items of the scale were appropriate for factor analysis. The structure validity of the scale was evaluated with principal components analysis using Varimax rotation. Factors with eigenvalues $>1$ were selected. Figure 2 shows that eigenvalues slightly decreased after component 5 . Five subdimensions were created and labelled as: daily life management (8 items), symptom management (6 items), medication management (11 items), emotional cognitive
Table 1 Demographic Characteristics of the Study Participants

\begin{tabular}{|c|c|}
\hline characteristics & $\mathrm{N}(\%)$ or $($ Mean $\pm \mathrm{SD})$ \\
\hline Age Mean, years(SD) & $54.78 \pm 10.03$ \\
\hline \multicolumn{2}{|l|}{ Gender } \\
\hline Male & $155(59.4 \%)$ \\
\hline Female & $106(40.6 \%)$ \\
\hline \multicolumn{2}{|l|}{ Civil status } \\
\hline Married & 236(90.4\%) \\
\hline Single & $7(2.7 \%)$ \\
\hline Divorced & $2(0.8 \%)$ \\
\hline Widowed & $9(3.4 \%)$ \\
\hline misses & $7(2.7 \%)$ \\
\hline \multicolumn{2}{|l|}{ Employment situation } \\
\hline Unemployed & $80(30.7 \%)$ \\
\hline Working & $84(32.2 \%)$ \\
\hline Retired & $52(19.9 \%)$ \\
\hline others & $45(17.2 \%)$ \\
\hline \multicolumn{2}{|l|}{ Level of education } \\
\hline Without studies & $26(10.0 \%)$ \\
\hline Primary education & $69(26.4 \%)$ \\
\hline Secondary education & 135(51.7\%) \\
\hline University education & $31(11.9 \%)$ \\
\hline \multicolumn{2}{|l|}{ Disease } \\
\hline Rectum cancer & $96(36.8 \%)$ \\
\hline Colon cancer & $70(26.8 \%)$ \\
\hline Gastric cancer & $47(18.0 \%)$ \\
\hline Breast cancer & $20(7.7 \%)$ \\
\hline Others & $28(10.7 \%)$ \\
\hline Course of disease, months(SD) & $54.84 \pm 10.19$ \\
\hline \multicolumn{2}{|l|}{ Medication } \\
\hline Capecitabine Capsule & $133(51.0 \%)$ \\
\hline Xelode Capsule & $66(25.3 \%)$ \\
\hline Tegafur Gimeracil Oteracil Potassium Capsule & $55(21.1 \%)$ \\
\hline Others & $7(2.7 \%)$ \\
\hline
\end{tabular}

management (7 items) and social support ( 4 items). The cumulative explained variance rate of the scale was $63.603 \%$, and the item factor loadings was $0.530-0.903$ (Table 2).

A four-point $(1=$ not relevant, 2 = weak relevant, $3=$ strong relevant, $4=$ very relevant) ordinal rating scale was used. The Scale-level CVI/ universal agreement (SCVI/UA) and the item-level CVI (I-CVI) of scale were calculated. According to the number of votes that each item received from the panel of 6 experts, S-CVI/UA was 0.833 and I-CVI of scale ranged from 0.833 to 1 (Table 3). The value of $\mathrm{S}-\mathrm{CVI} / \mathrm{UA}>0.8$ and I-CVI $\geqq 0.78$ mean good content validity. 


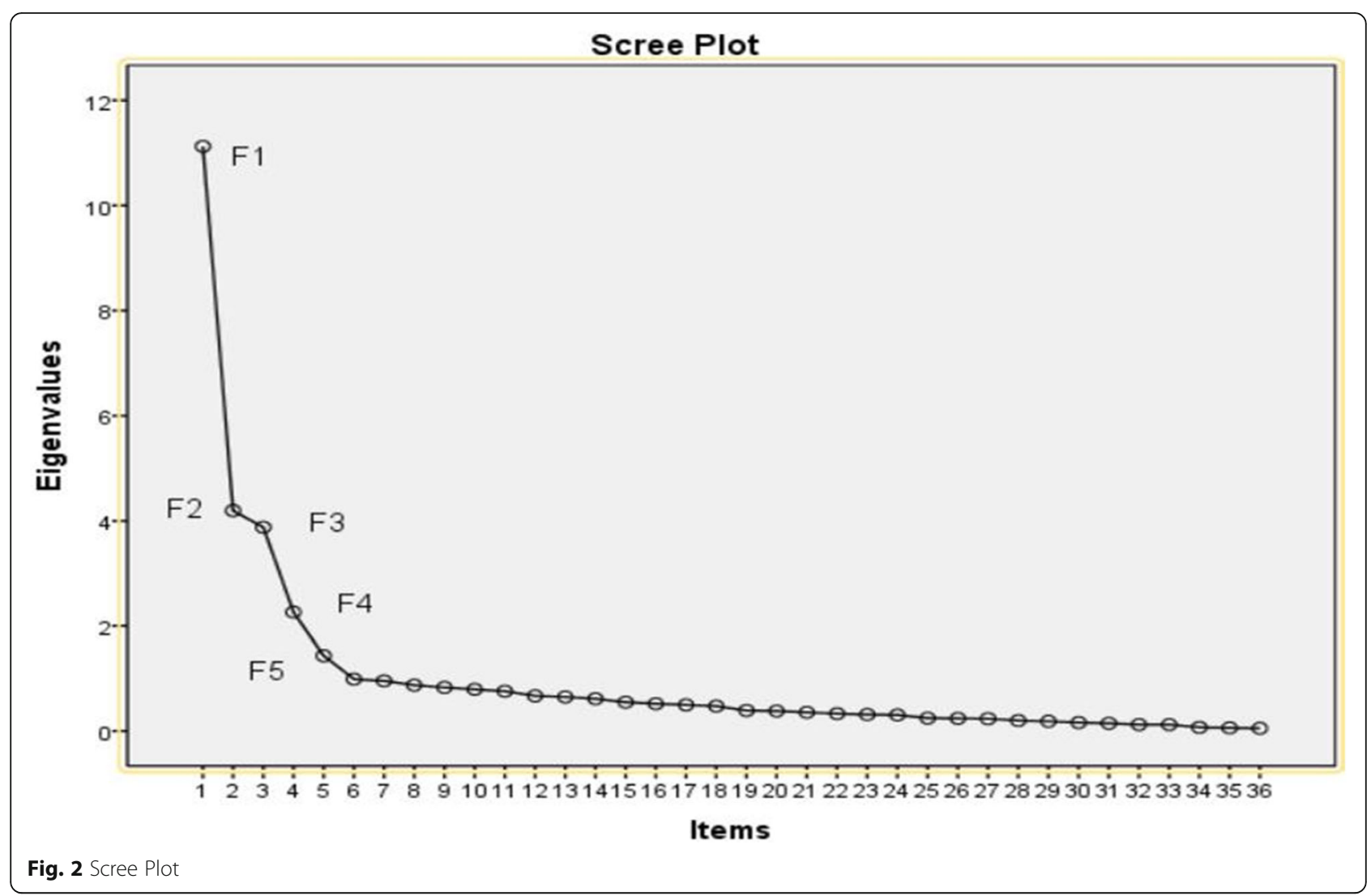

\section{Reliability of the scale}

The internal consistency coefficient "Cronbach's Alpha" of total scale was 0.929 with the Cronbach's Alpha of each factor at 0.664-0.927. The split-half coefficient of the total scale was 0.773 with the split-half coefficient of each factor at 0.584-0.919 (Table 4). The test-retest reliability of the total scale was $r=0.966$, which was statistically significant and indicated that the scale had good stability over time.

\section{Discussion}

\section{Reliability and validity of the scale}

The OCSMS exhibited good reliability and validity in a clinical sample of patients with oral chemotherapy. We calculated the Cronbach's Alpha to evaluate the unidimensionality of a set of items. The Cronbach's Alpha of OCSMS was 0.929 , suggesting that the items have relatively high internal consistency. The split-half coefficient and test-retest reliability were also high, implying that the OCSMS has good reliability.

The CVI of OCSMS was quite high, indicating that its items adequately represent the construct being measured. Factor analysis of the OCSMS revealed that the five sub-dimensions accounted for $63.603 \%$ of the total variance.

\section{Sub-dimensions of scale}

Some scholars believe that oral chemotherapy has the advantages of convenience and tolerance; however, its side effects still need to attract the attention of medical workers [18]. In the interview of this study, patients with cancer receiving oral chemotherapy reported that the most important thing is the lack of professional guidance, especially on adverse symptoms and medications. Therefore, the sub-dimensions of scale include symptom and medication management. Another is that patients have negative emotions, which may be related to the high mortality rate of the tumour. Negative psychology can induced the disease to deteriorate. Therefore, the indicators of this study include emotional cognitive management. On the basis of literature review and expert panel, five sub-dimensions were finally labelled as: daily life management, symptom management, medication management, emotional cognitive management and social support.

\section{Implications for clinical practices}

Oral cancer therapies have several advantages, including great flexibility and convenience for the patient and minimal disruption of daily activities [19]. However, some shortcomings, such as the need to self-manage drugs and identify adverse drug reactions, are also noted. 
Table 2 Item Factor Loadings

\begin{tabular}{|c|c|c|c|c|c|c|}
\hline Domains & Contents & $\begin{array}{l}\text { Factor } \\
1\end{array}$ & $\begin{array}{l}\text { Factor } \\
2\end{array}$ & $\begin{array}{l}\text { Factor } \\
3\end{array}$ & $\begin{array}{l}\text { Factor } \\
4\end{array}$ & $\begin{array}{l}\text { Factor } \\
5\end{array}$ \\
\hline \multirow[t]{8}{*}{$\begin{array}{l}\text { Daily life } \\
\text { management }\end{array}$} & $\begin{array}{l}1 \text { pay attention to the diet, choose digestible food high in vitamins (fresh } \\
\text { vegetables and fruit) and quality protein (such as fish, meat eggs and milk) }\end{array}$ & 0.648 & & & & \\
\hline & 2 frequent small meals, avoid irritating foods (such as spicy, cold food) & 0.693 & & & & \\
\hline & 3 drink more water; the daily amount of drinking water is more than $2000 \mathrm{ml}$ & 0.765 & & & & \\
\hline & 4 pay attention to your body weight change every week & 0.700 & & & & \\
\hline & 5 keep a regular sleep schedule, and guarantee $6-8 \mathrm{~h}$ of sleep every day & 0.903 & & & & \\
\hline & $\begin{array}{l}6 \text { exercise properly based on your own physical condition, such as walking, } \\
\text { square dance and Tai Chi }\end{array}$ & 0.783 & & & & \\
\hline & 7 your smoking situation during taking oral chemotherapy & 0.855 & & & & \\
\hline & 8 your drinking situation during taking oral chemotherapy & 0.815 & & & & \\
\hline \multirow{6}{*}{$\begin{array}{l}\text { Symptom } \\
\text { management }\end{array}$} & 9 understand the common adverse reactions of oral chemotherapy drugs & & 0.768 & & & \\
\hline & 10 readily identify the adverse symptoms of oral chemotherapy drugs. & & 0.810 & & & \\
\hline & 11 assess the severity of adverse symptoms caused by oral chemotherapy & & 0.699 & & & \\
\hline & 12 when a mild adverse reaction occurs, simple measures can be taken. & & 0.743 & & & \\
\hline & 13 when serious adverse reaction occurs, you can contact doctor timely. & & 0.606 & & & \\
\hline & 14 follow the doctor's advice and return to the hospital for regular review. & & 0.582 & & & \\
\hline \multirow[t]{11}{*}{$\begin{array}{l}\text { Medication } \\
\text { management }\end{array}$} & $\begin{array}{l}15 \text { understand the relevant knowledge of oral chemotherapy drug (including } \\
\text { drugs and course) }\end{array}$ & & & 0.842 & & \\
\hline & $\begin{array}{l}16 \text { actively consult on the knowledge and requirements of medication at the time } \\
\text { of treatment }\end{array}$ & & & 0.896 & & \\
\hline & 17 accept doctors' medication plan & & & 0.814 & & \\
\hline & $\begin{array}{l}18 \text { other daily information (such as other patients and advertisements) that will } \\
\text { affect your choice of medication plan }\end{array}$ & & & 0.558 & & \\
\hline & $\begin{array}{l}19 \text { store medication according to drug storage conditions, such as light, moisture } \\
\text { and temperature requirements }\end{array}$ & & & 0.687 & & \\
\hline & $\begin{array}{l}20 \text { check the completeness of the drug prior to ingestion (such as the } \\
\text { completeness of outer packaging and tablet defects) }\end{array}$ & & & 0.544 & & \\
\hline & 21 adjust the dosage according to the doctor's instructions & & & 0.701 & & \\
\hline & 22 take medicine on time according to the doctor's advice & & & 0.890 & & \\
\hline & 23 does not touch the chemotherapy drugs when taking the medicine & & & 0.860 & & \\
\hline & $\begin{array}{l}24 \text { the excrement can be cleaned up in time, and the toilet is continuously } \\
\text { flushed twice during the treatment }\end{array}$ & & & 0.693 & & \\
\hline & 25 understand the treatment of the remaining oral chemotherapy & & & 0.612 & & \\
\hline \multirow{7}{*}{$\begin{array}{l}\text { Emotional } \\
\text { cognitive } \\
\text { management }\end{array}$} & 26 able to communicate with friends or colleagues & & & & 0.770 & \\
\hline & 27 feel that my friends or colleagues treat me differently & & & & 0.892 & \\
\hline & 28 unconsciously vent my emotions to my family or friends during the treatment & & & & 0.764 & \\
\hline & 29 does not want to talk to anyone when feeling depressed & & & & 0.805 & \\
\hline & $\begin{array}{l}30 \text { can relieve stress through talking, watching } T V \text {, surfing the Internet, taking a } \\
\text { deep breath and meditating }\end{array}$ & & & & 0.779 & \\
\hline & 31 learn that negative emotions affect your body & & & & 0.833 & \\
\hline & 32 able to recognize their own emotional changes & & & & 0.577 & \\
\hline \multirow[t]{4}{*}{ Social support } & 33 be cared for and supported by family, friends or medical personnel & & & & & 0.530 \\
\hline & 34 actively participate in social activities within their capacity. & & & & & 0.616 \\
\hline & 35 actively exchange medication information with family members or caregivers & & & & & 0.691 \\
\hline & 36 actively communicate disease treatment information with medical personnel. & & & & & 0.688 \\
\hline
\end{tabular}


Table 3 Experts' Ratings and CVI Calculation $(N=6)$

\begin{tabular}{|c|c|c|c|c|c|c|c|c|}
\hline \multirow[t]{2}{*}{ Item } & \multicolumn{6}{|c|}{ Experts Ratings } & \multirow{2}{*}{$\begin{array}{l}\text { Number } \\
\text { of } 3 \text { or } 4 \\
\text { items }\end{array}$} & \multirow{2}{*}{$\begin{array}{l}\text { I- } \\
\text { CVI }\end{array}$} \\
\hline & $A$ & B & C & D & $E$ & $\bar{F}$ & & \\
\hline 1 & 3 & 4 & 4 & 4 & 4 & 4 & 6 & 1 \\
\hline 2 & 3 & 4 & 4 & 4 & 4 & 4 & 6 & 1 \\
\hline 3 & 3 & 4 & 4 & 4 & 4 & 4 & 6 & 1 \\
\hline 4 & 3 & 3 & 4 & 3 & 4 & 4 & 6 & 1 \\
\hline 5 & 3 & 3 & 4 & 3 & 4 & 4 & 6 & 1 \\
\hline 6 & 3 & 3 & 4 & 4 & 4 & 4 & 6 & 1 \\
\hline 7 & 3 & 3 & 3 & 2 & 3 & 3 & 5 & 0.83 \\
\hline 8 & 2 & 3 & 3 & 3 & 3 & 3 & 5 & 0.83 \\
\hline 9 & 4 & 4 & 4 & 4 & 4 & 4 & 6 & 1 \\
\hline 10 & 4 & 4 & 4 & 4 & 4 & 4 & 6 & 1 \\
\hline 11 & 4 & 4 & 3 & 4 & 4 & 4 & 6 & 1 \\
\hline 12 & 4 & 4 & 4 & 4 & 4 & 4 & 6 & 1 \\
\hline 13 & 4 & 4 & 4 & 4 & 4 & 4 & 6 & 1 \\
\hline 14 & 4 & 4 & 4 & 4 & 4 & 4 & 6 & 1 \\
\hline 15 & 4 & 4 & 4 & 4 & 4 & 4 & 6 & 1 \\
\hline 16 & 4 & 3 & 3 & 4 & 4 & 4 & 6 & 1 \\
\hline 17 & 4 & 4 & 3 & 4 & 4 & 4 & 6 & 1 \\
\hline 18 & 4 & 4 & 4 & 3 & 4 & 4 & 6 & 1 \\
\hline 19 & 4 & 3 & 4 & 3 & 4 & 4 & 6 & 1 \\
\hline 20 & 4 & 4 & 4 & 4 & 4 & 4 & 6 & 1 \\
\hline 21 & 4 & 4 & 4 & 4 & 4 & 4 & 6 & 1 \\
\hline 22 & 4 & 4 & 4 & 4 & 4 & 4 & 6 & 1 \\
\hline 23 & 4 & 4 & 4 & 4 & 4 & 4 & 6 & 1 \\
\hline 24 & 4 & 3 & 4 & 4 & 4 & 4 & 6 & 1 \\
\hline 25 & 4 & 4 & 4 & 4 & 4 & 4 & 6 & 1 \\
\hline 26 & 3 & 2 & 3 & 3 & 3 & 3 & 5 & 0.83 \\
\hline 27 & 3 & 3 & 2 & 3 & 3 & 3 & 5 & 0.83 \\
\hline 28 & 3 & 4 & 4 & 4 & 3 & 3 & 6 & 1 \\
\hline 29 & 3 & 3 & 4 & 4 & 4 & 4 & 6 & 1 \\
\hline 30 & 3 & 3 & 4 & 4 & 4 & 4 & 6 & 1 \\
\hline 31 & 3 & 3 & 4 & 4 & 4 & 4 & 6 & 1 \\
\hline 32 & 3 & 3 & 4 & 3 & 4 & 4 & 6 & 1 \\
\hline 33 & 3 & 3 & 4 & 3 & 4 & 4 & 6 & 1 \\
\hline 34 & 3 & 3 & 4 & 3 & 3 & 3 & 6 & 1 \\
\hline 35 & 4 & 4 & 3 & 3 & 4 & 2 & 5 & 0.83 \\
\hline 36 & 3 & 4 & 3 & 3 & 2 & 3 & 5 & 0.83 \\
\hline
\end{tabular}

Therefore, the patients' self-management ability is important. Lack of self-management can lead to adverse consequences that may affect therapeutic outcomes and patients [20]. Existing research focused on patient's compliance [21-23]. Prior to this study, no instrument has been designed to assess the self-management ability of patients with oral chemotherapy. A qualitative study [24]
Table 4 Cronbach's Alpha and Split-half Coefficient of each Domain

\begin{tabular}{lll}
\hline Domains & $\begin{array}{l}\text { The Cronbach's } \\
\text { Alpha }\end{array}$ & $\begin{array}{l}\text { The split-half } \\
\text { coefficient }\end{array}$ \\
\hline Daily life management & 0.920 & 0.858 \\
Symptom management & 0.869 & 0.865 \\
Medication management & 0.927 & 0.901 \\
$\begin{array}{l}\text { Emotional cognitive } \\
\text { management }\end{array}$ & 0.904 & 0.919 \\
Social support & 0.664 & 0.584 \\
\hline
\end{tabular}

showed that self- management should be assessed for patients with oral chemotherapy; hence, a tool for this aspect must be developed. Nurses can give proper health education to patients with poor self-management ability. This tool could be used to ensure the safety of patients with cancer receiving oral chemotherapy at home.

\section{Study limitations}

Our study has a number of limitations. First, The research was conducted only in China. Cross-cultural validation studies are necessary. Second, Although the OCSMS was found to have a five-factor structure and good reliability, more research is needed to establish its concurrent or convergent validity or discriminant validity. Third, The sample size $(n=261)$ was 6.87 times the number of items (38 times), so further studies with larger sample size is required to validate the OCSMS.

\section{Conclusion}

The OCSMS has high reliability and validity and takes only a few minutes to complete. Patients with cancer receiving oral chemotherapy reported that this scale is easy to take and can evaluate their self-management ability.

\section{Abbreviations}

OCSMS: Oral chemotherapy self-management scale; KMO: Kaiser-meyer-olkin; CVI: Content validity index; S-CVI/UA: Scale-level CVI/ universal agreement; ICVI: Item-level CVI

\section{Acknowledgements}

The authors gratefully acknowledge the study participants and the hospital staff.

\section{Authors' contributions}

QP wrote the manuscript, analyzed the data.wyw contributed to the revision of the manuscript and data collection. All authors have reviewed the manuscript and given final approval of the version to be published.

\section{Funding}

This work was supported by Zhejiang Province Health Medicine Science and Technology Backbone Platform Project (2016RCA004), Youth research fund project of Zhejiang Cancer Hospital (QN201804) and Zhejiang Province Health Medicine Science and Technology Plan Project (2020KY082). The funding body played no role in the design of study, collection, analysis and interpretation of data, or in writing the manuscript.

Availability of data and materials

All data supporting the findings are included in this publication. 


\section{Ethics approval and consent to participate}

This study was approved by the medical ethics committee of ZheJiang Cancer Hospital, Hangzhou, Zhejiang, China. Patients provided their written informed consent prior to responding to the research.

\section{Consent for publication}

Not applicable.

\section{Competing interests}

The authors declare that they have no competing interests.

Received: 14 May 2020 Accepted: 14 September 2020

Published online: 16 September 2020

\section{References}

1. Catania C, Didier F, Leon ME, et al. Perception that oral anticancer treatments are less efficacious: development of a questionnaire to asses the possible prejudices of patients with cancer. Breast Cancer Res Treat. 2005;92(3):265-72.

2. Simons S, Ringsdorf S, Braun M, et al. Enhancing adherence to capecitabine chemotherapy by means of multidisciplinary pharmaceutical care. Support Care Cancer. 2011;19(7):1009-18.

3. Johnson TM. Long-term care: safe drug handling of Oral chemotherapy. Consult Pharm. 2017;32(2):74-83.

4. Ribed A, Romero-Jimenez RM, Escudero-Vilaplana V, et al. Pharmaceutical care program for onco-hematologic outpatients: safety, efficiency and patient satisfaction. Int J Clin Pharm. 2016;38(2):280-8.

5. Komatsu H, Yagasaki K, Yamaguchi T. Effects of a nurse-led medication selfmanagement programme in cancer patients: protocol for a mixed-method randomised controlled trial. BMC Nurs. 2016;15:9.

6. Ozdelikara A, Tan M. The effect of reflexology on chemotherapy-induced nausea, vomiting, and fatigue in breast Cancer patients. Asia Pac J Oncol Nurs. 2017:4(3):241-9.

7. Kinney J, Kahana E, Corbin JM, Strauss A. Unending work and care: managing chronic illness at home. San Francisco: Jossey-Bass Pubilshers; 1989.

8. Richard AA, Shea K. Delineation of self-care and associated concepts. J Nurs Scholarsh. 2011:43(3):255-64.

9. Wei C, Nengliang Y, Yan W, Qiong F, Yuan C. The patient-provider discordance in patients' needs assessment: a qualitative study in breast cancer patients receiving oral chemotherapy. J Clin Nurs. 2017;26(1-2):12532.

10. Spoelstra SL, Given BA, Given CW, et al. An intervention to improve adherence and management of symptoms for patients prescribed oral chemotherapy agents: an exploratory study. Cancer Nurs. 2013;36(1):18-28.

11. Persell SD, Karmali KN, Lee JY, et al. Associations between health literacy and medication self-management among community health center patients with uncontrolled hypertension. Patient Prefer Adherence. 2020;14: 87-95.

12. Persell SD, Karmali KN, Lazar D, et al. Effect of electronic health record-based medication support and nurse-led medication therapy management on hypertension and medication self-management: a randomized clinical trial. JAMA Intern Med. 2018;178(8):1069-77.

13. Peng $Q$, Wu WY. A study on status and demand of Oral chemotherapy selfmanagement among Cancer patients at home. Chin J Rural Med Pharm. 2020;27(14):31-2.

14. Wang $\mathrm{SN}$, Dong $\mathrm{R}$, Xie $\mathrm{H}$, et al. Delphi method and its application Progress in constructing index system. J Bengbu Med Coll. 2019;25(10):1233-7.

15. Peng Q, Wu WY, Liang GM, et al. Construction of self-management assessment indicators for cancer patients with oral chemotherapy at home. Chin J Mod Nurs. 2019;25(10):1233-7.

16. Peng $Q$, Yu XY, Wu WY. Review of oral anticancer chemotherapeutic agents regulation mode among community-dwelling cancer patients. Chin J Mod Nurs. 2018;24(26):3214-6

17. MacCallum RC, Widaman KF, Zhang S, Hong S. Sample size in factor analysis. Psychol Methods. 1999;4(1):84-99.

18. May P, LaPlant K, McGee A. Practice model: establishing and running an Oral chemotherapy management clinic. Asia Pac J Oncol Nurs. Oct-Dec 2017;4(4):299-303.

19. Schneider SM, Adams DB, Gosselin T. A tailored nurse coaching intervention for oral chemotherapy adherence. J Adv Pract Oncol. 2014;5(3):163-72.
20. Wong SF, Bounthavong M, Nguyen C, Bechtoldt K, Hernandez E. Implementation and preliminary outcomes of a comprehensive oral chemotherapy management clinic. Am J Health Syst Pharm. 2014;71(11): 960-5.

21. Jacobs JM, Ream ME, Pensak N, et al. Patient experiences with Oral chemotherapy: adherence, symptoms, and quality of life. J Natl Compr Cancer Netw. 2019;17(3):221-8.

22. Allen J, Williamson S. Over compliance with capecitabine oral chemotherapy. Int J Clin Pharm. 2014;36(2):271-3.

23. Dowling $M$, Hunter $A$, Biesty $L$, et al. Driving and disabling factors of noncurative Oral chemotherapy adherence: a qualitative evidence synthesis. Oncol Nurs Forum. 2019;46(1):16-28.

24. Morris $\mathrm{M}$, Marshall-Lucette $\mathrm{S}$. The experience of myeloma caregivers during home-based Oral chemotherapy treatment: a qualitative study. Semin Oncol Nurs. 2017;33(3):362-71.

\section{Publisher's Note}

Springer Nature remains neutral with regard to jurisdictional claims in published maps and institutional affiliations.

Ready to submit your research? Choose BMC and benefit from:

- fast, convenient online submission

- thorough peer review by experienced researchers in your field

- rapid publication on acceptance

- support for research data, including large and complex data types

- gold Open Access which fosters wider collaboration and increased citations

- maximum visibility for your research: over $100 \mathrm{M}$ website views per year

At BMC, research is always in progress.

Learn more biomedcentral.com/submissions 